\title{
PEMBAHARUAN PENDIDIKAN ISLAM DI INDONESIA
}

\author{
Oleh: \\ Saidur Ridlo ${ }^{1}$ \\ Email: saidurridlo3@gmail.com
}

\begin{abstract}
The long journey of Islamic education has colored the tumult of models of Islamic education in various regions, especially in Indonesia itself, Islamic education also took the momentum of turmoil and renewal in various parts of other Islamic regions. That Effect had a significant impact to call it a change, both in the ideological and practical domains. Of course That turmoil has colored the reform process and determine the goal of renewal of Islamic education in Indonesia, on the other hand, the result of it sometimes made a resistence which illustrates how dynamic the journey of Islamic education in Indonesia, It can be seen from the diversity of Islamic education models that have taken root for years, moreover, the seeds of Islamic educational institutions have flourished several centuries ago.
\end{abstract}

Keywords: islamic education, indonesia, reform, renewal

\section{Pendahuluan}

Perlu dicatat bahwa pendidikan Islam telah memancing perhatian umum yang membuat berbagai diskusi dan perbincangan yang cukup serius. Ketertarikan terhadap tema-tema dalam pendidikan Islam yang dibahas dan diangkat dalam beragam seminar, konferensi internasional, kelas, majelis, bahkan dalam bentuk publikasi. Menjadi sebuah interest untuk melihat dan memformulasikan kajian yang dinamis dalam pendidikan Islam.

Pada tahun 1977 diadakan "First World Conference on Muslim Education" yang berlangsung di Makkah, ${ }^{2}$ kemudian hampir seterusnya

${ }^{1}$ Dosen IAI Al Khoziny Buduran Sidoarjo

${ }^{2}$ Kegiatan ini menjadi konferensi pertama pendidikan Muslim yang hadir di sana Prof.Naquibal-Attassebagai mantan Director of International Institute of Islamic Thought and Civilization (ISTAC) dan member of the International Advisory Board of 
diadakan kegiatan yang senada. Seperti kegiatan yang agak serius membicarakan reformasi pendidikan Islam pada tahun 2011 yaitu konferensi internasional Reform in Islamic Education di University of Cambridge, Inggris.

Dalam konferensi tersebut disebutkan bahwa reformasi dalam pendidikan Islam adalah salah satu 'proyek' yang paling penting dari pembaharuan dan reformasi Islam, masyarakat muslim sejak awal abad kedua puluh dan seterusnya. ${ }^{3}$ Logika dibalik reformasi tersebut disebut Azra bagi umat Islam untuk dapat mengatasi dunia modern dan mencapai kemajuan, dengan tidak ada cara lain kecuali reformasi pendidikan Islam. ${ }^{4}$

Menggejalanya kemajuan Eropa pada waktu itu sampai sekarang otomatis bagi tubuh Islam bukan sebagai tontonan belaka. Dengan bertahan pada ketradisionalan tentunya sama saja Islam akan semakin terbelakang dan tidak sanggup menghadapi segala macam kebutuhan manusia yang terus meningkat, sembari terus terjadinya kontinuitas penetrasi Barat ke dunia Islam yang berlangsung sampai sekarang. Alhasil Islam yang selalu bersandar pada otensitas wahyu Tuhan (al-Qur'an) tidak mampu berkembang, selama wahyu Tuhan hanya dianggap teks sakral

the Muslim Education Foundation (MEF). Disana ia menyampaikan gagasan dan pandangannya tentang pendidikan Islam dalam tulisannya yang berjudul The Concept of Edcuation inIslam.

${ }^{3}$ AzyumardiAzra, "ReformsinIslamicEducation:A Global Perspective Seen from the Indonesian Case”,dalam Paul Anderson, et.all (ed), Reforms in Islamic Education, (University of Cambridge, 2011), hlm.3

${ }^{4}$ Ibid, harus diakui bahwa reformasi di bidang pendidikan Islam telah bertemu dengan beberapa perlawanan dari beberapa masyarakat Muslim yang menaruh curiga bahwa reformasi hanya akan mengarahkan siswa Muslim untuk menjauh dari Islam dan beralih kepada sekularisme. Namun, gagasan dan upaya reformasi pendidikan Islam sebenarnya mendapatkan momentum baru dalam peristiwa 9 September 2001 yang lalu di AS. Padahal seharusnya oleh banyak pihak bahwa salah satu yang paling penting akar penyebab radikalisme di kalangan umat Islam adalah bahwa pendidikan Islam dianggap sebagai institusi kuno. Oleh karena itu, pendidikan Islam telah bertanggungjawab karena gagal untuk memberikan perspektif yang lebih baik bagi anakanak Muslim untuk melihat dunia di sekitar mereka. Di samping itu, pendidikan Islam, khususnya madrasah dan lembaga-lembaga pendidikan Islam tradisional lainnya seperti pesantren di Indonesia telah disalahartikan sebagai 'berkembang biak radikalisme' atau 'talibanism'. 
tanpa mengambil spirit utamanya. Maka dalam kondisi seperti yang demikian, Azra menyatakan:

"Menanggapi hal semacam persepsi atau kesalahan persepsi, ada kebutuhan mendesak untuk meninjau kembali reformasi dalam pendidikan Islam setelah satu abad berlalu. Meskipun reformasi telah dilakukan dalam waktu yang lama di berbagai masyarakat dan negara-negara Muslim, jelas bahwa tingkat reformasi dalam pendidikan Islam berbeda dari satu tempat ke tempat lain. Ada kasus bahwa reformasi dalam pendidikan Islam telah sangat sukses; tetapi ada juga kasus di mana reformasi pendidikan Islam telah gagal. Keberhasilan dan kegagalan reformasi dalam pendidikan Islam memiliki banyak hubungannya dengan berbagai faktor agama, politik dan sosial yang bekerja dalam masyarakat muslim tertentu dan negara". ${ }^{5}$

Apa yang dilihat sampai sejauh ini, "mungkin" pendidikan Islam masih terus dianggap belum mampu menjawab berbagai tantangan dan kebutuhan (need) umat manusia. Padahal disadari atau tidak pendidikan agama Islam sudah berlangsung lama ada sejak awal penyebarannya. Fazlurrahman menyebutkan seperti keterampilan membaca dan menulis dalam sistem pendidikan Islam dimulai semenjak kedatangan Islam dan semakin meningkat didukung oleh ekspansi (penyebaran) Islam itu sendiri. Begitupun di nusantara, parapedagangArab yang berdagang selain berdakwah ia juga memberikan pendidikan secara tidak langsung melalui ajaran-ajaran normatif Islam.

Hanya saja perjalanan pendidikan Islam sejauh ini seperti grafik naik turun dan terus menurun, kadang-kadang malah di satu sisi hanya berputar-putar di zona halal-haram. Seperti di masa klasik dan pertengahan persoalan pendidikan Islam didominasi pelajaran agama sedang ruang ilmu-ilmu profan (seperti filsafat, sosial, ilmu alam, kedokteran untuk menyebutnya beberapa) begitu sedikit ruangnya. Legitimasi terhadap ilmu-ilmu agama dipandang lebih utama untuk

\section{${ }^{5}$ Ibid}

Volume 11 Nomor 1 Maret 2020 
melanggengkan jalan "kesalehan" menuju Tuhan ketimbang ilmu-ilmu umum.

Di Indonesia sendiri pendidikan Islam mulanya masih harus berhadapan dengan pendidikan Belanda. Masa kolonialisasi menunjukkan suramnya pendidikan bagi masyarakat pada umumnya, hanya orang-orang tertentu yang bisa mengenyam pendidikan di sekolah-sekolah Belanda. Sedangkan pendidikan Islam belum diakui sebagai pendidikan resmi. Hanya mengandalkan basis keluarga dan masyarakat secara informal saja pendidikan Islam intens terselenggara oleh masyarakat untuk menengah ke bawah.

Lambat laun kemudian mulai bermunculan lembaga pendidikan Islam yang lebih banyak lahir dari masyarakat seperti Surau di Padang, di Aceh terdapat Meunasah, Dayah dan Rangkang, di Jawa terdapat pesantren, dan di beberapa tempat lainnya dengan nama yang beragam. ${ }^{6}$ Pendidikan Islam terus berkembang dengan lahirnya lembaga pendidikan selain pesantren dengan menyebutnya madrasah, yang tidak lain juga terinisiasi dari bentuk sekolah umum di satu sisi dan pesantren disisi keagamannya. Kemudian pula lahirnya sekolah- sekolah Islam yang sebenarnya memiliki basis dari ormas-ormas Islam yang sudah lebih dulu ada seperti Muhammadiyah, Persis, dan NU. Sampai akhirnya muncul Pendidikan Tinggi Agama Islam sebagai kelanjutan tingkatan dari lembaga pendidikan Islam di Indonesia.Sampai hari ini semua bentuk lembaga pendidikan Islam ini mengalami perkembangan yang signifikan namun terkadang terlihat stagnan untuk menyebutnya di beberapa sisi kurang bergairah dan menjanjikan dari kualitas begitupun lulusannya.

Sayangnya terkadang lembaga pendidikan Islam ramai-ramai dibuka dan didirikan namun terkesan dibiarkan begitusaja, karena kelahirannya belum dilandasi dari visi yang matang. Di satu sisi begitu antusiasnya harapan masyarakat untuk lahirnya pendidikan Islam sebagai tempat pendidikan bagi generasi terdidik, tetapi di sisi lain meninggalkan PR bagi pengelola dan lembaga-lembaga pendidikan Islam tidak mampu

${ }^{6}$ Abudin Nata, Sejarah Sosial Intelektual Islam dan Institusi Pendidikannya, (Jakarta: Rajawali Pers, 2012), hlm. 292-298 
memberikan pendidikan yang terbaik, apalagi untuk bersaing dengan pendidikan umum.

Momentum perbaikan dalam reformasi pendidikan lebih kurang sudah berlangsung sejak awal abad ke 20 di Indonesia, dimana kesadaran mulai muncul dari gelombang pembaruan Islam sendiri. Karel tidak menampik jika kondisi yang terjadi di Indonesia ini disebutnya sebagai kebangkitan dan renaissance (pencerahan) terahap pembaruan Islam di Indonesia. ${ }^{7}$ Jika sebelumnya kedatangan Islam di Indonesia pada abad ke 13 sebetulnya tidak begitu kreatif di bidang keilmuan dan di bidang politik, dimana karena Islam sudah "masuk" zamankemunduran. Jika gambaran ini diteruskan sampai abad ke-19, pastilah kelemahan Islam di Indonesia pada bidang perkembangan ilmu sebetulnya diakibatkan oleh kemunduran Islam secara internasional. ${ }^{8}$

Latar belakang ini tentunya tidak salah untuk mengagendakan pembaharuan dan reformasi dalam tubuh pendidikan Islam, terutama di Indonesia. Apalagi momentum bangsa Indonesia dilihat dari perjalanan perpolitikan bangsa kadangkala memberikan kesempatan baik bagi pendidikan Islam, namun dikesempatan lain terkadang belum memberikan ruang yang pas untuk menyebut pendidikan Islam belummampu bersaing dengan pendidikan umum lainnya.

Mengingat luasnya topik pembahasan ini, maka penulis berusaha membatasinya pada lembaga pendidikan Islam yang adadi Indonesia dengan melihat secara singkat sisi pembaharuan yang terjadi di dalamnya. Ulasanyangditampilkan dalam makalah ini dicoba melalui gaya dan pendekatan sejarah karena mengingat pentingnya pendekatan ini dalam kajian sejarah pendidikan Islam. ${ }^{9}$

\footnotetext{
${ }^{7}$ Karel A. Steenbrink, Pesantren, Madrasah, Sekolah, (Jakarta: LP3ES, 1974), hlm 26

${ }^{8}$ Karel A. Steenbrink, Beberapa Aspek Tentang Islam di Indonesia Abad Ke-19, (Jakarta: Bulan Bintang, 1984), hlm.5

${ }^{9}$ Literatur berbahasa Indonesia yang mulai serius dalam memperhatikan pentingnya pendekatan sejarah dalam studi Islam adalah buku "Sejarah Sosial dalam Studi Islam" karya Ach.Minhaji yang banyak memberikan makna dan seluk-beluk pendekatan sejarah (Hystories Approache) dalam kajian keislaman. Penekanan yang mendalam dengan menggunakan pendekatan ini menurutnya masih jarang digunakan dalam Studi 


\section{Memaknai Reformasi Pendidikan Islam}

Pendidikan Islam selama ini baik dari kelembagaan, penyelenggaraan, serta dari sisi keilmuan begitu banyak mengalami ketertinggalan, sehingga "urgensi" dari reformasi dalam tubuh pendidikan Islam mau tidak mau harus dilakukan.

Makna reformasi memiliki orientasi dan kecenderungan terhadap perbaikan, rekonstruksi, pembaharuan dan kontinuitas dalam membawa trend positif. Maka melihat gagasan reformasi bagi ruang pendidikan adalah hal yang harus disambut positif. Karena dalam reformasi pendidikan menginginkan penyempurnaan setiap kekurangan untuk seterusnya dilakukan penanaman kesadaran untuk dapat siap menghadapi perubahan zaman.

Reformasi di sini bisa juga disebut dengan pembaharuan atau modernisasi, dalam artian luas, mereformasi pendidikan Islam dengan maksud untuk menambal semua kekurangan dan menyiapkan segala kemungkinan kedepan. Hal ini terjadi dalam pendidikan Islam bermula dengan dominasi dari kemajuan Eropa (Barat) yang pada waktu itu menguasai ilmu pengetahuan, disaat yang bersama kekuatan Islam melemah seiring kekalahan demi kekalahan melawan Barat. Dengan kata lain bentuk-bentuk pembaharuan serta modernisasi yang terjadi dalam

Islam. Lihat Ach. Minhaji, Sejarah Sosial dalam Studi Islam, (Yogyakarta: Suka Press, 2012). Pengkajian terhadap pendidikan Islam dengan menggunakan pendekatan sejarah murnipun disadari oleh Azyumardi Azra masih sangat minim dilakukan oleh para sarjana dan peneliti di Indonesia. Hal ini bisa dilihat dari jumlah disertasi yang ditulis para mahasiswa di berbagai perguruan Tinggi Islam (IAIN, UIN). Azyumardi Azra, Pendidikan Islam; Tradisi dan Modernisasi di tengah Tantangan Milenium III, (Jakarta: Kencana, 2012), hlm.. Hal yang sama pula sebenarnya telah lama disadari oleh Fazlurrahman, bahwa dalam pengkajian Islam sendiri pendekatan dan metode kesejarahan telah banyak diterapkan oleh para orientalis seperti David S. Margoliouth, Ignaz Goldziher, Henry Lammen, Joseph Schact, H.A.R.Gibb, N,J. Coulson, William Montgomery Watt. Namun bagi kalangan muslim disadari akan kurangnya perspektif kesejarahan di kalangan muslim pada gilirannya menyebabkan minimnya kajian-kajian sejarah Islam. Menurutnya umat Islam memerlukan kajian kesejarahan agar mereka dapat menimbang lebih lanjut nilai-nilai perkembangan sejarah tersebut untuk melakukan rekonstruksi disiplin-disiplin ilmu Islam untuk masa depan. Lihat, Sutrisno, Fazlurrahman; Kajian Terhadap Metode, Epistemologi dan Sistem Pendidikan, (Jogyakarta: Pustaka Pelajar, 2006), hlm. 122, lihat pula Fazlurrahman, Islam and Modernity, hlm.151. 
lembaga pendidikan merupakan bagian dari reformasi karena memiliki spirit dalam menentukan kebutuhan dan perbaikan di masa depan.

Dalam hal pemikiran, gagasan reformasi Islam sendiri adalah usaha mengungkapkan nilai-nilai yang esensial dan menjelaskan halhal yang berkaitan erat dengan Islam yang disalahtafsirkan orang; atau suatu pemikiran dan metode atau sistem yang berdasarkan atas kritik yang konstruktif yang hanya mengakui nilai, yaitu nilai Islam untuk menuntun umat Islam. Ada juga yang mengartikan reformasi Islam sebagai gerakan pembaharuan yang disponsori Muhammad Abduh yang bertujuan menyadarkan kaum muslimin dan membangkitkan Islam keluar dari kebekuan serta membersihkannya dari unsur- unsure yang tidak murni Islam, menuntut kembali kemurnian Islam dan membebaskan diri dari kekangan mazhab abad pertengahan. ${ }^{10}$

Kecenderungan gerakan pembaharuan yang dilakukan para pemikir dan intelektual Islam di berbagai negara Islam telah memancing dan membangkitkan kesadaran dan memberikan efek bagi pendidikan Islam itu sendiri. Seperti yang sudah disebut seperti Abduh, kemudian juga Jamaludin, M. Iqbal, Maududi dan di Indonesia misalnya ada Ahmad Dahlan, yang mana mereka memiliki kesadaran akan keterbelakangan Islam yang semakin "akut". Makna pembaharuan yang menuntut untuk dilakukan reformasi dan dekonstruksi terhadap pendidikan Islam merupakan aktualisasi dari kesadaran agar menarik diri dari "sumur dangkal" ketertinggalan.

Reformasi pendidikan Islam yang berlangsung di Indonesia dimaknai melalui perjalanannya mungkin sedikit berbeda dari negara lainnya. Dimana peran serta negara dan masyarakat terjadi kolaborasi. Pendidikan Islam di Indonesia sebelumnya lebih banyak lahir dari kesadaran masyarakat. Peran masyarakat dan pemerintah terhadap pendidikan Islam memiliki hubungan saling mendukung, sehingga dapat dilihat sudah banyak pendidikan Islam yang terlembagakan secara formal bahkan dinegerikan sejauh ini.

${ }^{10}$ Burhanuddin Daya, Gerakan Pembaharuan Pemikiran Islam; Kasus Sumatera Thawalib, (Yogyakarta: Tiara Wacana, 1995), hlm. 46 
Sedangkan di negara Islam datang (Arab Saudi, Afghanistan, Syiria dan Mesir hanya untuk menyebutnya beberapa saja) reformasi pendidikan Islam dimaknai atas bentuk kecurigaan, terkadang berbau tendensi teologis, dan dianggap oleh kaum konservatif membahayakan. Tak jarang yang terjadi kooptasi antara dua kubu yang mengkritik kejumudan dengan para penguasa lembaga pendidikan. Sehingga yang ada malah legitimasi terhadap agama selalu hadir dan sulit untuk disingkirkan. Tentunya gambaran semacam ini sudah lama ditinggalkan dalam tubuh pendidikan Islam di Indonesia yang sejauh ini dalam berberapa hal diluar dugaan mengalami perkembangan yang signifikan.

\section{Landasan Pembaharuan Pendidikan Islam}

Tentunya isu pembaharuan pendidikan tidak bisa dilepaskan dari perkembangan pemikiran dalam Islam sendiri. Kontribusi besar yang membawa ruh segar dalam semangat melakukan pembaharuan terlahir dari semangat-semangat kritik pembaharuan yang dilakukan oleh kalangan Islam sendiri. Hal ini tidak lain berangkat dari kesadaran atas keterbelakangan Islam dalam segala hal.

Seperti yang diungkapkan Azra bahwa yang disebut dalam literatur sebagai pembaruan pendidikan pada esensinya adalah pembaruan pemikiran dan perspektif intelektual.11 Beberapa intelektual dan pemikir Islam di belahan dunia Islam seperti Maududi di Pakistan, Wahhab di Saudi, Abduh di Mesir, Gulen Movement di Turki dan lainnya, mereka memberikan gagasan penting sebagai bentuk kritik ambivalensi pelaksanaan bagi pendidikan umat Islam yang bersifat kaku, tekstualis, dan rigid. Hal ini tentu berimbas pada wajah pendidikan Islam pada waktu itu. Apalagi di dunia Islam, pengajaran pendidikan Islam di awal abad pertengahan kecenderungan yang dilihat hanya berorientasi pada aspek kognitif, dengan kurang menimbangkan dua aspek lainnya, afektif dan psikomotorik.

${ }^{11}$ Azyumardi Azram, Pendidikan Islam; Tradisi dan Modernisasi di Tengah Tantangan Milenium III, (Jakarta: Kencana, 2012), hlm. xiv

Volume 11 Nomor 1 Maret 2020

Approved: 01-03-2020, Accepted: 15-03-2020, Submitted: 26-03-2020 


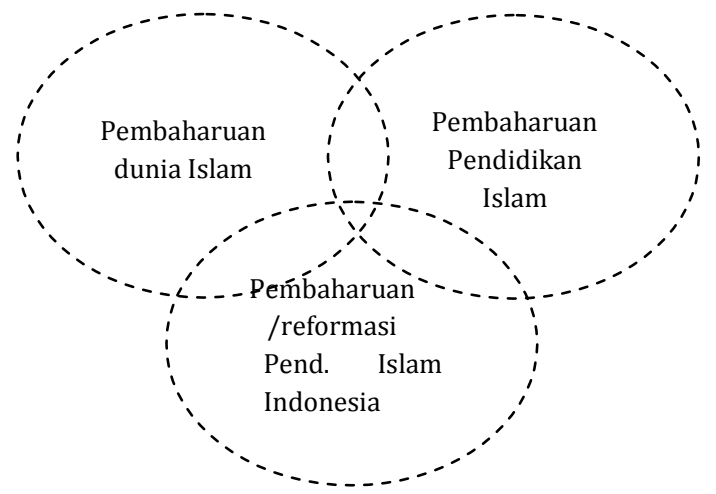

\section{Gambar 1. Keterkaitan Terjadinya Reformasi Pendidikan Islam}

Di Indonesia pembaharuan ini terjadi di permulaan abad ke 20, dimana Karel menyebutnya sebagai kebangkitan, pembaharuan, bahkan pencerahan (renaissance). Pembaruan pendidikan Islam di Indonesia dilatarbelakangi oleh aspek pembaharuan Islam itu sendiri, dengan menggaris bawahi empat faktor pendorong penting bagi perubahan itu; Pertama, Semenjak tahun 1900 di beberapa tempat muncul keinginan untuk kembali kepada Qur'an dan Sunnah yang dijadikan titik tolak untuk menilai kebiasaan agama dan kebudayaan yang ada. Kedua, didorong oleh sifat perlawanan nasional terhadap penguasa kolonial Belanda. Ketiga, adanya usaha yang kuat dari orang-orang Islam untuk memperkuat organisasinya seperti Sarekat Islam dan Muhammadiyah. Keempat, dorongan pembaharuan pendidikan Islam sendiri, dimana banyak orang dan organisasi Islam yang tidak puas dengan metode tradisional dalam mempelajari Qur'an dan agama. ${ }^{12}$

Dari segi keilmuan yang dikembangkan pendidikan Islam hanya berorientasi pada ranah theosentris ilmu-ilmu ketuhanan dan kurang menaruh pada ranah antrophosentris yaitu ilmu-ilmu umum dan kealaman. Sampai beberapa abad kondisi ini terus berlanjut dengan nuansa kenormatifannya, sedangkan pintu ijtihad ditutup dengan menganggap segala hal sudah final. Sedangkan Barat sudah mulai

${ }^{12}$ Karel A. Steenbrink, Pesantren, hlm. 26-28 
beralih kepada antroposentris dan ilmu-ilmu profane dengan terus sampai melahirkan beragam penemuan baru. Tinggal ratapan saja yang terjadi bagi tubuh umat Islam melihat barat sudah jauh ke depan.

Hasil pendidikan yang demikian dipastikan tidak menghasilkan ilmuwan muslim yang dapat membangunkan tidur panjang Islam dari lemahnya penguasaan ilmu pengetahuan. Dari sini ironisnya seperti dikatakan Amin Abdullah: "hampir- hampir tidak ada satu pun umat Islam yang yang menorehkan tinta emas dalam pengembangan ilmu pengetahuan". 13 Umat Islam menjadi umat konsumtif, serta ilmu pengetahuan pun berubah kiblat tidak lagi di dunia Islam tetapi dunia Barat yang sempat berguru pada Islam.

\section{Resistensi Terhadap Pembaharuan Pendidikan Islam}

Arti penting dari pembaharuan dan reformasi yang dilakukan para intelektual muslim dunia sangat berpengaruh terhadap Pendidikan Islam di Indonesia. Ahmad Dahlan misalnya yang terisnspirasi terhadap pemikiran Abduh dan Jamaluddin, sehingga ketika pulang ke tanah air ia mengusung pendidikan Islam yang mengenalkan corak baru dengan sistem klasikal, yang sebelumnya masih berbentuk talaqqi, bandongan dan wetonan. Dalam bidang keagamaan ia mungkin lebih dulu mengkritisi tradisi yang menurutnya dianggap tidak benar telah menyimpang dan terlalu banyak tradisi-tradisi yang bergeser dari tuntunan Rasulullah.

Tawaran pendidikan tersebut ternyata tidak berjalan mulus, masyarakat umum memandangnya sebagai kyai kafir, terlebih lagi ia mendirikan sekolah Islam dengan sistem ala pendidikan Belanda dan tidak pernah diperkenalkan dalam Islam. Sedangkan Belanda jelas-jelas pada waktu itu statusnya adalah musuh nyata umat Islam di Indonesia. Maka segala hal yang berbau Belanda sulit diterima umat Islam di samping karena faktor traumatik kolonialisasi yang begitu panjang dirasakan bangsa Indonesia.

${ }^{13}$ M. Amin Abdullah, Profil Kompetensi Akademik; Lulusan Program Pascasarjana Perguruan Perguruan Tinggi Islam dalam Era Masyarakat Berubah dalam makalah yang disampaikan pada Pertemuan dan Konsultasi Direktur Program Pasca Sarjana Perguruan Tinggi Agama Islam, Hotel Setiabudi, Jakarta, 24-25 Nopember 2002. 
Ahmad Dahlan ingin mengubah cara pendidikan yang selama itu terkesan monoton dan tidak menginspirasi bagi peserta didik. Di kesempatan lain ia mengajarkan murid-muridnya sembari menggunakan alat musik, dan turun ke lapangan. Sedangkan pendidikan agama yang diajarkan tidak pernah berlangsung demikian.

Memang betul pendidikan Islam pada waktu itu diajarkan kebanyakan dengan metode menghafal. Dan ini tidak menampik masih pengaruh dari sistem pendidikan di dunia Islam lainnya. Fazlurrahman menilai mulai abad pertengahan pendidikan Islam dilaksanakan secara mekanis yang lebih cenderung pada aspek kognitif dari pada aspek afektif. Strategi yang digunakan masih bersifat defensif, yaitu menyelamatkan pikiran kaum muslimin dari pencemaran atau kerusakan yang ditimbulkan oleh gagasan-gagasan Barat terutama yang mengancam akan kerusakan moral Islam. ${ }^{14}$ Memasuki era kontemporer pendidikan Islam pun juga masih menghadapi beragam problem pembelajaran yang tidak kreatif.

Jika pada pesantren yang dikenal dengan sikap eksklusif dan tertutup sebenarnya pembaharuan bukan terjadi penolakan di sana, namun lebih kehati-hatian pesantren dalam segala hal yang baru. Kondisi ini tentunya logis dimana pesantren hampir sepanjang masa penjajahan dalam bahasanya Madjid "mengasingkan diri" dari dunia luar. Tapi secara perlahan pesantren disatu sisi melihat pembaharuan sebagai nafas keberlangsungan pendidikan tradisionalnya di kancah modernisasi.

Seperti yang terjadi di Indonesia, gelombang pembaharuan juga sebelumnya sudah terjadi di dunia Islam lainnya abad ke 19. Arah baru pendidikan yang ditawarkan Abduh, Jamaluddin Al Afghani, Fazlurrahman, dan oleh beberapa intelektual muslim selalu menghadapi resistensi di masanya. Ada yang mampu membuka kesadaran masyarakat namun ada pula yang belum mampu berbuat banyak karena kuatnya penguasa dan arus dominan penolakan pada waktu itu. Abduh sendiri tidak mampu berkuasa penuh dalam pembaharuan pendidikan di Al

\footnotetext{
${ }^{14}$ Sutrisno, Pembaharuan dan Pengembangan Pendidikan Islam, (Yogyakarta: Fadila Tama,2011), hlm.8
} 
Azhar untuk memasukkan pengetahuan umum dalam kurikulum $\mathrm{Al}$ Azhar.

Dengan begitu, di sini bahwa dapat dijelaskan pembaharuan pendidikan Islam terutama di Indonesia tidak terjadi begitu saja. Dimana ada faktor-faktor di luar itu yang pastinya mengalami benturan baik aspek politik, teologi, sosial, dan kebudayaan menjadi alasan yang dapat kita lihat dalam sejarahnya. Saat ini reformasi pendidikan Islam beberapa saat terkadang dihadapkan dengan perlawanan dan penolakan kecil dari kalangan masyarakat muslim ketika tawaran keilmuan baru yang di usung oleh dunia akademisi, di beberapa perguruan tinggi, khususnya PTAI. Dari segi keilmuan umat Islam masih memandang carang pandang ulama klasik masih kuat dipegang. Seperti metode-metode penafsiran hermeneutik, teori-teori studi Islam dari para orientalis, dan sebagainya terkesan masih alergi dan bahkan ada istilah "haram" untuk dipakai.

Namun penulis berpendapat pembaharuan pendidikan Islam lebih sedikit beruntung sebenarnya dari pembaharuan di tempat lain, pendidikan Islam yang dimotori pesantren kemudian terjadi reformasi disana-sini tidak selamanya mengalami resistensi, bahkan seringkali muncul harapan-harapan dari masyarakat yang sudah menanti lama hadirnya pendidikan Islam yang memenuhi espektasi semua kalangan.

\section{Kebijakan Reformasi Pendidikan Islam}

Di Indonesia, penerapan pendidikan termasuk pendidikan Islam dipengaruhi oleh banyak faktor, salah satunya adalah kebijakan politik oleh pemerintah. Ini dapat dilihat dari perjalanan pendidikan Islam dari masa ke masa bagaimana terjadinya diskriminasi dan pengabaian pendidikan Islam dari masa klonialisasi sampai Orde Baru. Sehingga tampak sangat kentara kelemahan dan kekurangan pendidikan Islam dan harus dilakukan perbaikan secara terus menerus.

Institusi pesantren, sekolah, dan madrasah di Indonesia memiliki karakteristik tersendiri yang dapat dibedakan satu dengan lainnya, khususnya porsi materi pelajaran agama serta afiliasinya dengan kementerian terkait. Pesantren, memuat materi agama secara dominan, 
sedangkan sekolah umum memberikan alokasi waktu dua jam pelajaran agama dalam satu minggunya, sementara madrasah sebelum tahun 1975 meliputi materi agama $70 \%$ dan materi umum 30\%. Setelah SKB 3 menteri pada tahun 1975, komposisinya dibalik menjadi $30 \%$ materi agama dan $70 \%$ materi umum. Meskipun demikian, khusus untuk madrasah, pada tahun 1986 diselenggarakan madrasah pilot project (MAN PK) yang mengikuti komposisi materi agama 70\% dan materi umum $30 \% .15$

Bagi tubuh pesantren, sepakat dengan pernyataan Nurcholis Madjid bahwa tidak perlu diragukan lagi terkait dengan sejarah pesantren sebagai pendidikan asli indegionus Indonesia. Tetapi lagi-lagi sebagai bangsa yang dijajah, pendidikan pesantren hampir-hampir tidak pernah diperhitungkan sebelumnya sebagai bagian dari pendidikan nasional. Posisi pesantren sebagai resistensi perlawanan kolonialisasi Belanda yang memilih menolak penjajahan mengambil jalur untuk mengasingkan diri ('uzlah). Alhasil Belanda berhasil menyingkirkan dunia pesantren dari pendidikan Indonesia. Keberadaannya seperti makhluk ghaib antara ada dan tiada. Ada karena terlahir dari dan mengakar kuat di masyarakat, tetapi tidak ada karena selalu tidak diperhitungkan keberadaannya. Padahal kondisi ini berbalik di dunia Barat, yang hampir pendidikan bertolak dari lembaga pendidikan keagamaan.

Berangkat dari situ kemudian sebagai kesadaran pentingnya pesantren dalam sejarah pendidikan di Indonesia, maka berbagai produk kebijakan yang menginginkan perbaikan di dunia pesantren mulai muncul. Kebijakan dalam pesantren dimana pada masa kolonial Belanda pesantren secara penuh mengajarkan pendidikan agama, namun kemudian pesantren menyadari perubahan zaman yang terus menuntut berbagai macam kebutuhan, sehingga pesantren mulai memasukkan pelajaran umum dan mengadopsi sistem pembelajaran klasikal seperti madrasah.

${ }^{15}$ M. Shabir U, Kebijakan Pemerintah dan Pengaruhnya Terhadap Pendidikan Islam di Indonesia, dalam Jurnal Lentera Pendidikan, Vol.16 No.2 Desember 2013, hlm. 169 
Madrasah sendiri di Orde Lama sekitar tahun 1958-1959, oleh Kementrian Agama pernah memperkenalkan Madrasah Wajib Belajar (MWB) yang berbasis pada pembangunan masyarakat pedesaan dengan meliputi pengetahuan agama dan keterampilan. Namun akhirnya karena tidak berjalan dengan baik program ini tidak dilanjutkan. Pada masa awal Orde Baru antara tahun 1967-1970 dilakukan penegerian di lingkungan Madrasah Tsanawiyah (MTs) dan Madrasah Aliyah (MA) serta mengubah nama dan struktur madrasah negeri. Selanjutnya, tahun 1975, melalui SKB 3 Menteri, madrasah berusaha ditingkatkan mutu pendidikannya. ${ }^{16}$

Kebijakan Pendidikan Agama Islam di sekolah juga berbeda dari masa colonial Belanda, dimana sekolah umum tidak diperkenankan memasukkan pelajaran agama. Tetapi kemudian terjadi perubahan kebijakan di masa pemerintahan Jepang yang membolehkan memasukkan pendidikan agama. Setelah Indonesia merdeka, dinyatakan dengan tegas bahwa pendidikan agama perlu dijalankan di sekolah-sekolah negeri. Hasil kerja Panitia Penyelidik Pengajaran memutuskan bahwa pelajaran agama diberikan pada semua sekolah dalam jam pelajaran, sedangkan di Sekolah Rakyat (SD) diajarkan mulai kelas IV. Guru agama disediakan oleh Kementerian Agama dan dibayar oleh pemerintah, dengan ketentuan bahwa guru agama harus mempunyai pengetahuan umum. Berdasarkan alasan tersebut diperlukan pendidikan guru agama. ${ }^{17}$

Yuridis formal dalam UUSPN No.2 Tahun 1989 maupun UUSPN No. 20 Tahun 2003 menjadi landasan kebijakan yang menekankan bahwa pendidikan agama berhak diterima oleh setiap peserta didik baik di tingkat dasar, menengah, dan perguruan tinggi. ${ }^{18}$

\footnotetext{
${ }^{16} \mathrm{Ibid}, \mathrm{hlm} .171$

${ }^{17}$ Ibid, hlm. 172

${ }^{18}$ Sebagaimana yang terlihat pasal 1 ayat 5 UUSPN 2003 yang menyebutkan bahwa: Pendidikan Nasional adalah pendidikan yang berdasarkan Pancasila dan UndangUndang Dasar Negara Republik Indonesia Tahun 1945 yang berakar pada nilai-nilai agama, kebudayaan nasional Indonesia dan tanggap terhadap perubahan zaman". Pasal 4 UUSPN 2003; "Pendidikan nasional bertujuan mengembangkan potensi peserta didik agar menjadi manusia beriman dan bertakwa kepada Tuhan Yang Maha Esa, berakhlak mulia,
} 
Perubahan-perubahan kebijakan terkait pendidikan agama di sekolah dan perguruan tinggi terus terjadi. Terutama sekolah dan perguruan tinggi yang berada di bawah ormas-ormas Islam. Tidak hanya pada jam pelajaran dan mata kuliah, namun alternatif penambahan muatan pelajaran agama melalui kegiatan-kegiatan ekstra kurikuler yang disesuaikan seperti: Rohis, IPM, IPNU, IMM dan sebagainya yang bernafaskan Islam.

Adapun kebijakan pembaharuan dari sisi tenaga pendidik, guru pendidikan Islam juga menjadi sorotan. Pasalnya kritik terhadap kualitas lulusan dari lembaga pendidikan Islam dipandang masih rendah. Faktorfaktor yang mempengaruhi salah satunya kualitas tenaga pendidiknya. Hari ini dunia pendidikan menghadapi tantangan yang luar biasa, dimana pendidik harus siap mampu memberikan pengajaran. Era teknologi tidak dipungkiri telah merasuki segala sendi kehidupan umat Islam, derasnya informasi dari segala arah bisa dinikmati, dan persaingan pendidikan umum yang sudah lama memanfaatkan kemajuan ini harus diimbangi.

Pendidik/guru di lembaga pendidikan Islam tentu tidak bisa berdiam diri. Usaha dalam memperbaiki kualitas guru seperti yang terjadinya mismatch kesarjanaan guru dengan mata pelajaran yang di ampu. Dalam kebijakan pemerintah munculnya Undang-undang Guru dan Dosen No. 14 Tahun 2005 yang mewajibkan setiap guru di sekolah megajarkan sesuai dengan bidang keahliannya. Dengan begitu para guru di setiap lembaga pendidikan Islam juga harus menyesuaikan peraturan pemerintah tersebut karena pendidikan Islam sudah termasuk dalam sistem pendidikan nasional.

berbudi mulia, sehat, berilmu, kompeten, terampil, kreatif, mandiri, estetis, demokratis, dan memiliki rasa kemasyarakatan dan kebangsaan". Pasal 13 ayat 1 huruf A UUSPN 2003; Setiap peserta didik pada setiap satuan pendidikan berhak mendapatkan pendidikan agama sesuai dengan agama yang dianutnya dan diajarkan oleh pendidik yang seagama. Lihat Samsul Nizar dan M. Syaifudin, Isu-isu Kontemporer Tentang Pendidikan Islam, (Jakarta: kalam Mulia, 2010), hlm. 245, lihat pula UU Sisdiknas., hlm.5-11 


\section{Pembaharuan Lembaga Pendidikan Islam}

Lembaga pendidikan Islam memiliki beragam bentuk. Di tiap negara tentulah berbeda-beda, meskipun dalam sejarahnya terkadang ada kesamaan nama seperti madrasah Nidzamiah pada masa Dinasti Abbasiyah berbeda dengan madrasah yang ada di Indonesia. Madrasah yang ada di Indonesia secara pelaksanaan berangkat dari inisiatif masyarakat sebagai kepedulian pendidikan sedangkan madrasah Nidzamiah diselenggarakan oleh negara. Maka, hampir-hampir pendidikan Islam di Indonesia mulanya lebih banyak di sponsori oleh masyarakat daripada negara sendiri, yang kemudian hari dilembagakan secara resmi. Ikut serta negara dalam penyelenggaraan pendidikan Islam sendiri awalnya dari pelajaran agama Islam di sekolah-sekolah umum.

Untuk menyederhanakan, Sutrisno mengkategorikan lembaga pendidikan Islam kedalam dua garis besar, pertama; pendidikan dasar yang terdiri dari pesantren, sekolah islam, pai di sekolah umum, dan madrasah. Kedua; Perguruan Tinggi Agama Islam.

Disini penulis tidak banyak menyebutkan sejarah masing-masing lembaga ini, namun berupaya menampilkan pembaharunnya yang terjadi dimasing-masing lembaga ini. ${ }^{19}$

Pada reformasi dan pembaharuan bagi pesantren tidak terjadi begitu saja. Karena pesantren disebut Azra memiliki sikap sangat berhati-hati dengan segala yang disebut pembaharuan. Dengan ungkapan lain sikap yang dilakukan pesantren adalah "menolak sambil mengikuti". Apalagi slogan yang selalu dipegang al muhafadzotu 'ala qodimi as shalih wa al akhdzu bi al jadidi al aslah selalu dipegang sebagai jati diri pesantren.

Tapi pesantren beberapa dekade terakhir tidak begitu mainstream menolak beragam perubahan. Orientasi tafaqquh fiddin sebagai produk yang menghasilkan ulama tentunya sudah lama terjadi. Kontinuitas dalam reproduksi ulama adalah harapan pasti yang tidak pernah terputus dalam mata rantai penyokong ulama. Oleh

${ }^{19}$ Sutrisno, Pembaharuan., hlm. 39 
karena itu, meski pesantren terkadang sering dikritik karena menampilkan bentuk sentralistik pada kharisma personal kyai, sehingga ada yang menilai sebagai bentuk religio feodalisme sehingga membatasi keran kreatifitas santri dan guru lainnya.

Namun jika dibandingkan dengan pendidikan semacam pesantren di negara lain, ternyata pesantren sebagai lembaga institusi pendidikan yang paling merespon perubahan. Dimana pesantren saat ini sudah mulai bertransformasi dalam berbagai bentuk perubahan. Disaat dunia global dan modernisasi mulai menggejala pesantren tidak tanggung- tanggung ikut serta dalam percaturan dunia modern.

Pesantren di satu sisi berorientasi di bidang keagamaan, bersamaan dengan itu pesantren meningkatkan kemampuan life skill santri di bidang vocational, pertanian, perkebunan/agrobisnis, peternakan dan keterampilan di bidang ekonomi lainnya. Penulis sendiri di sebelum lulus di tahun 2008 pernah juga mendapatkan pendidikan agrobisnis dan pertanian cara merawat tanaman sawit dan karet semacam itu di pesantren. Pesantren dipandang mampu berperan dalam peningkatan perekonomian secara mandiri, sedangkan pemerintah biasanya mendukung dengan bantuan-bantuan yangdibutuhkan pesantren, misalnya pelatihan dengan mendatangkan instruktur, bibit, ternak, dan sebagainya.

Gontor menjadi contoh dimana pembaharuan aspek kelembagaan, manajemen, dan kurikulum pesantren sudah berjalan baik. Ide pembaharuan pendidikan pesantren sudah muncul sejak awal pesantren ini berdiri di tahun 1926.20 Gerakan pembaharuan (harakat al-tajdid wa al-islah al-dini wa al-ijtima'i) di bidang pendidikan oleh Gontor sebagai pelopor pembaruan pendidikan pesantren.

Menurut Mukti Ali usaha pembaharuan sistem pengajaran dan pendidikan di pesantren di lakukan dengan: (1) mengubah kurikulum supaya berorientasi pada kebutuhan masyarakat, (2) kurikulum ala wajib belajar hendaknya digunakan sebagai patokan untuk pembaharuan itu, (3) mutu guru-gurunya hendaknya ditingkatkan,

${ }^{20}$ Samsul Nizar dan M.Syaifudin, Isu-isu Kontemporer, hlm.198

Volume 11 Nomor 1 Maret 2020

Approved: 01-03-2020, Accepted: 15-03-2020, Submitted: 26-03-2020 
juga prasarana-prasarana pendidikan diperbaharui, (4) usaha pembaharuan ini hendaknya dilaksanakann secara bertahap dengan didasarkan pada hasil-hasil penelitian yang seksama tentang kebutuhan riil masyarakat yang sedang membangun, (5) hasil usaha pembaharuan ini memakan waktu panjang, (6) pada hakikatnya, pembangunan dan pembaharuan sudah amat mendesak. ${ }^{21}$

Dengan begitu menarik tentunya melihat kemampuan pesantren bertahan di saat gencarnya pembaruan dan modernisasi hampir di seluruh kawasan dunia Islam, sedangkan yang lain mulai tergusur dan hilang oleh dominasi sistem pendidikan umum. Sehingga menarik disini bahwa pendidikan tradisional pesantren dalam beberapa hal masih relevan di era sekarang ini. Begitu pun dengan tanda- tanda persaingan yang mulai mampu mengimbangi pendidikan di luar pesantren.

Ada yang unik sebenarnya jika memperhatikan kondisi pesantren, dimana-mana pesantren kadangkala "dituntut" agar diseragamkan dengan lembaga pendidikan lainnya. Setara dalam pelajaran dan bobot materi katakanlah dengan sekolah umum. Padahal pesantren sampai saat ini bertahan dengan keunikannya. Pesantren seharusnya tidak merasa perlu menghilangkan ciri khas dan keunikannya yang sudah mengakar kuat jauh dari sebelum lembaga pendidikan lainnya. Bahkan ironisnya lagi pesantren sebenanrya adalah lembaga yang "hebat" namun seringkali "dikerdilkan" keberadaannya. Di Indonesia merasa tidak memiliki apa-apa padahal sebelumnya orang-orang luar melakukan studi banding di pesantren yang dipandang mereka sebagai lembaga pendidikan yang luar biasa.

Untuk itu kadangkala yang menjadi kelemahan sendiri bagi pesantren adalah diseragamkannya dengan sekolah-sekolah lain, namun tidak mampu memenuhi eskpektasi standar minimum. Sehingga yang terjadi adalah serba tanggung dan terkesan apa adanya. Kelemahan ini mulai banyak menjangkiti lembaga pesantren

${ }^{21}$ Sutrisno, Pembaharuan, hlm. 61, Lihat pula A. Mukti Ali, Beberapa Masalah Pendidikan di Indonesia, hlm.23

Volume 11 Nomor 1 Maret 2020

Approved: 01-03-2020, Accepted: 15-03-2020, Submitted: 26-03-2020 
yang seyogyanya kekhususan dan keunikannya harus dilestarikan dengan bentuk dan format yang berbeda dari pendidikan lainnya.

Karena secara historis pesantren inilah satu-satunya lembaga pendidikan yang lebih dulu lahir di Indonesia dibandingkan dengan lembaga pendidikan lainnya, maka tak heran sebagai Indigiounus produk bangsa semestinya berbangga dengan memajukan dan membanggakan pesantren di tengah kondisi dan keberadaannya yang saat ini kurang populer. Padahal berkaca pada lembaga-lembaga pendidikan maju di luar sana mulanya adalah dari lembaga pendidikan keagamaan seperti halnya pesantren.

Perkembangan madrasah pun di Indonesia juga tak kalah menarik. Sejarah panjang madrasah sebelum kemunculan "wajah baru" nya adalah sejarah tentang marginalisasi dan keterbelakangan. Tetapi sejak awal 1970-an, berkat Menteri Agama, Profesor A. Mukti Ali, merintis jalan ke arah transformasi madrasah dan juga perguruan tinggi Islam. Momentum itu, dalam berbagai kesempatan disebut sebagai "mainstream of Islamic education" pengarusutamaan pendidikan Islam; tegasnya, dari yang semula berada di pinggrian menuju ke "tengah", ke dalam arus utama pendidikan nasional Indonesia secara keseluruhan. ${ }^{22}$

Upaya mengangkat citra madrasah yang kurang menguntungkan mulai diperbaiki oleh kementrian Agama melalui serangkaian kebijakan seperti SKB-3 Menteri yang mengakui ijazah tamatan madrasah untuk digunakan melanjutkan ke sekolah umum. ${ }^{23}$ Maka dari situ lahirlah UU Nomor 20 tahun 1989 tentang UUSPN yang memasukkan madrasah sebagai bagian dari sistem pendidikan nasional. Sehingga madrasah sudah sama kedudukannya dengan sekolah umum, dengan begitu meningkatnya animo masyarakat terhadap pendidikan madrasah. Transformasi tersebut disambut

${ }^{22}$ Azyumardi Azra, Pendidikan Islam, hlm.95

${ }^{23}$ Samsul Nizar dan M. Syaifudin, Isu-isu Kontemporer, hlm. 200

Volume 11 Nomor 1 Maret 2020

Approved: 01-03-2020, Accepted: 15-03-2020, Submitted: 26-03-2020 
baik oleh masyarakat yang sudah lama memperjuangkan kesetaraan pendidikan madrasah dengan sekolah umum. ${ }^{24}$

Selain itu, sekolah-sekolah Islam yang banyak berkembang hampir kebanyakan inisiatif yang didirikan oleh ormas-ormas Islam seperti Muhammadiyah, NU dan sebagainya. Dilihat dari periodenya pada masa penjajahan mungkin Muhammadiyah yang lebih dulu menjadi sekolah Islam dengan mengadopsi pendidikan seperti Belanda. Dari muatan pelajaran dimasukkan ilmu-ilmu agama dan juga ilmu-ilmu umum. Sekolah-sekolah Muhammadiyah hampir ditiap daerah tumbuh beriringan dengan jumlah ribuan sekolah sampai hari ini (jika dihitung dari tingkat dasar sampai menengah atas). Pelajaran agamanya lebih bervariasi dengan jam pelajaran yang lebih banyak dari pada pelajaran agama di sekolah umum dengan ciri khas tersendiri.

Orde Baru disebut Sutrisno, muncul sekolah-sekolah yang mengadopsi sistem Muhammadiyah, seperti sekolah Islam al-Azhar, Madania, Athirah di Makasar, Sultan Agung di Semarang, al-Khairat di Surabaya, dan masih banyak lagi. ${ }^{25}$ Sampai era reformasi semakin terbukanya dalam dunia pendidikan tidak dapat terelakkan semakin banyaknya tumbuh sekolah-sekolah Islam yang menampilkan program-program unggulan. Sekolah-sekolah ini ada yang menyebutnya sekolah Islam Terpadu (IT), sekolah unggulan Islam, dan sekolah Islam plus. Dengan mengadopsi dari bentuk-bentuk pendidikan Islam sebelumnya seperti menggunakan sistem boarding school (asrama yang ada di pesantren), menggunakan bahasa internasional baik Arab dan Inggris sebagai program unggulan, ataupun sistem full day yang ditawarkan.

Pada level Perguruan Tinggi, pembaharuan perguruan Tinggi Agama Islam di Indonesia (selanjutnya disebut PTAI) paling kentara akhir-akhir ini adalah perubahan status IAIN menjadi UIN. Konversi ini dilandasi pada kampus-kampus Islam selama ini belum

\footnotetext{
${ }^{24}$ Azyumardi Azra, Pendidikan Islam, hlm.101

${ }^{25}$ Sutrisno, Pembaharuan, hlm. 80
} 
dipandang memberikan kontribusi yang nyata dalam dunia akademik. Penguasaan teknologi yang jauh dari harapan, dikotomisasi ilmu agama dan umum serta fasilitas yang belum memumpuni menjadi alasan tersendiri perlunya terjadi perubahan tersebut.

Secara kelembagaan perubahan status beberapa PTAIN memiliki sejarah panjang, namun kesungguhan untuk melakukan pembaharuan di atas kemudian memunculkan gairah keilmuan bagi kalangan PTAIN. Dimana harapan yang sudah lama dinantikan umat Islam Indonesia disambut dengan respon positif di berbagai kalangan.

Sekedar menyebutnya beberapa, seperti fakultas Kedokteran dan Psikologi, Ekonomi, Fisipol dan Saintek di UIN Syarif Hidayataulah Jakarta, Prodi Teknik Informatika, Psikologi, Teknik Komunikasi, dan Ilmu Hukum di UIN Sunan Kalijaga Yogyakarta. Demikian pula prodi- prodi baru yang dibuka di beberapa UIN dan IAIN lainnya. ${ }^{26}$

Mandat bagi PTAIN untuk mengembangkan keilmuan umum selain ilmu keislaman mencoba untuk mengintegrerasikan keduanya. Landasan idealnya meski dalam tubuh umat Islam terjadi dikotomisasi namun sebenarnya Islam tidak mengenal hal yang demikian. Para intelektual muslim sebelumnya membuktikan bahwa selain mereka ahli dalam urusan agama mereka memiliki kemampuan dalam berbagai bidang keilmuan seperti kedokteran, fisika, geologi, astonomi dan lain-lain.

Pembaharuan dalam PTAI tidak hanya terhenti pada perubahan kesadaran paradigm keilmuan, namun PTAI sampai hari ini mulai menjajaki kerjasama di berbagai perguruan tinggi baik dalam maupun luar negeri. Salah satunya dengan rutin mengirim para mahasiswa dan dosen dalam bentuk beasiswa studi, pertukaran, dan visiting. Baik mahasiswa dan tenaga dosen di lingkungan PTAI selayaknya membutuhkan keterbukaan wawasan (opening horizon) keilmuan. Sebelumnya hampir kebanyakan PTAI banyak melakukan kiblatnya pada Al Azhar namun pergeseran mulai terlihat dengan dilakukannya kerjasama dengan beberapa perguruan tinggi di Eropa.

${ }^{26}$ Ibid, hlm.87-88

Volume 11 Nomor 1 Maret 2020

Approved: 01-03-2020, Accepted: 15-03-2020, Submitted: 26-03-2020 
Sangat disadari bahwa Barat dan Eropa saat ini memiliki kemajuan ilmu pengetahuan dan pendidikan. Berbagai riset penelitian di berbagai bidang, jurnal-jurnal internasional yang terakreditasi, dan beragam kampus yang menduduki ranking terbaik dunia adalah bukti dari pendidikan umat Islam masih tertinggal jauh dan terpinggirkan. Maka logis selanjutnya PTAI Indonesia harus belajar banyak dari Eropa untuk meningkatkan kapasitas pendidikannya agar mampu bersaing di kancah global.

Meski espektasi inisiasi pendirian Perguruan Tinggi Islam mulanya sebagai pencetak ulama, namun harus mampu pula dibekali dengan keahlian teknologi dan keilmuan daya saing global yang melahirkan ilmuwan-ilmuwan muslim yang memiliki kontribusi nyata dalam kehidupan manusia saat ini. Meski dalam upayanya senantiasa untuk bertahan dan bangkit, sampai sejauh ini PTAI di Indonesia sudah mengalami loncatan-loncatan kemajuan yang signifikan.

\section{Agenda Reformasi Pendidikan Islam di Era Kekinian}

Azyumardi Azra menilai jika pendidikan Islam di Indonesia adalah yang paling reformir dan inovatif. Dimana masyarakat muslim dalam pendidikan Islam Indonesia memiliki "imajinary social", yang terbuka pada pluralitas dan inovasi baik yang muncul dari Islam dan kaum muslimin Indonesia sendiri maupun dari luar.

Disamping itu menurutnya kekuatan pemerintah disatu sisi menjadi keniscayaan dalam reformasi pendidikan Islam. Dimana proses tantangan modern yang dihadapi umat Islam tidak dapat menafikan peranan pemerintah dalam sebagai bagian structural negara yang bertanggungjawab terhadap pendidikan. Proses penegaraan pendidikan Islam bukti langkah reformasi yang disponsori oleh pemerintah. Seperti madrasah yang tersebar di Indonesia yang $80 \%$ adalah milik swasta dan sisanya 20\% milik pemerintah. Baik dibawah Kementrian Agama maupun Kementrian Kebudayan dan Pendidikan. Pembaharuan pendidikan tidak boleh terhenti dalam makna ideal. Pendidikan Islam harus mencari format-format baru untuk dapat terus relevan di setiap 
perkembangan zaman. Karena memahami hakikat Islam yang sholih likulli az zaman waalmakan akan lebih bermakna jika segala kemampuan dan usaha (termasuk mengagendakan pendidikan) dapat menyelesaikan segala permasalahan kehidupan umat manusia saat ini.

Pertautan keilmuan saat ini tentu menjadi kunci untuk menyadari betapa pentingnyapenguasaan keahlian dan keilmuan di berbagai bidang. Kehidupan umat manusia tidak hanya berkutat dalam ranah teologi, tetapi kehidupan pranatasosialharusdibangundenganmenguasai ilmu-ilmu selain agama; sosial, antroplogi, fisika, biologi dan sebagainya. Maka Gagasan integrasi keilmuandalampendidikanIslamsudahmenjadi keniscayaan, tentulah dari sini harus ada visi dan misi pendidikan Islam yang jelas dalam mengagendakan pendidikan Islam kedepan. Baik dari level pendidikan dasar, menengah, dan perguruan Tingginya.

Dunia Pendidikan Islam dituntut menyeimbangkan dengan visi pendidikan dunia, dimana UNESCO menggarisbawahi arah pendidikan saat ini setidaknya menimbangkan bagaimana learning to think (belajar bagaimana bepikir), learning to do (belajar hidup atau bagaimana berbuat/bekerja), learning to be (belajar bagaimana tetap hidup atau sebagai dirinya), learning to live together (belajar untuk hidup bersama).

Perbaikan visi pendidikan Islam jika tidak dibenahi dan para pengelola pendidikan Islam tidak memiliki semangat kepeloporan untuk berkreasi, berimprovisasi, dan berinovasi, dikhawatirkan milenium ketiga akan menjadi "liang kubur" bagi lembaga-lembaga pendidikan Islam. Untuk bisa survive, lembaga-lembaga pendidikan Islam harus tampil sebagai lembaga pendidikan alternatif, memiliki ciri dan keunggulan tersendiri. ${ }^{27}$ Disamping itu harus disadari tidak harus selamanya bernostalgia pada kejayaan masa lalu yang masih saja meninabobokkan dari tidur panjang umat Islam.

Umat Islam dihadapkan dengan persaingan global yang kian terbuka. Di depan mata semua orang sedang mempersiapkan agenda gelombang perekonomian global yang sudah di depan mata seperti

\footnotetext{
${ }^{27}$ Muhammad Sirozi, Agenda Strategis Pendidikan Islam, (Yogyakarta: AK Group, 2004), hlm. 68
} 
AFTA (Asean Free Trading Area) dan MEA (Masyarakat Ekonomi ASEAN). Jika tidak menyadari dan mempertimbangkan situasi ini, umat Islam Indonesia dipastikan tidak akan berperan banyak. Pendidikan Tinggi sebagai kunci strategis untuk mempersiapkan sumber daya yang mampu bersaing di kancah global harus mulai mensetting dan berani meningkatkan kapasitas keilmuan kontemporer yang tidak lagi terjadi dikotomisasi dan mulai membetulkan benang kusut berbagai problematika pendidikan Islam.

\section{Simpulan}

Memahami arti reformasi pendidikan harus dengan membuka mata selebar-lebarnya. Dengan artian bahwa saatnya dunia pendidikan sebagai sarana memajukan peradaban dijadikan langkah strategis penyiapan sumber daya manusia yang berkualitas. Maka dengan demikian mendorong untuk perlunya perbaikan, pembaharuan dan pengembangan pendidikan yang kontinuitas tanpa henti.

Pendidikan Islam meski disadari terkadang masih tertinggal namun di satu sisi dapat menggembirakan dengan capaian-capaian yang ada saat ini. Upaya untuk dapat setara dan bersaing dengan pendidikan umum menjadi keseriusan dalam perjalanannya, seperti pesantren yang diakui termasuk sebagai sistem pendidikan nasional dan madrasah yang memiliki kesetaraan dengan pendidikan umum lainnya hanya beberapa contoh saja dari usaha tersebut. Nada optimisme ini terlihat dari upaya-upaya dan hasil yang ada. Dimana pendidikan Islam bukan lagi pendidikan kelas dua dan pinggiran, namun loncatan-loncatan tadi sudah mulai terjadi dengan segala usaha yang dilakukan.

Sebagai kebijakan reformasi pendidikan, desentralisasi dan otonomisasi dalam lembaga pendidikan harus dimanfaatkan untuk upaya kreatif dalam melaksanakan pendidikan di masing-masing lembaga. Lembaga pendidikan Islam harus memberikan tawaran nuansa baru dan pendidikan Islam yang berdaya saing. Keleluasaan dan kewenangan yang demikian memberikan kebebasan untuk 
mandiri dan mampu berdiri tanpa harus selalu menunggu bantuan dari pemerintah. Walaupun demikian peran pemerintah juga memiliki andil yang besar dalam memajukan pendidikan Islam di Indonesia. Kolaborasi disetiap elemen memperkuat sejatinya lembaga pendidikan Islam yang selalu dinantikan sebagai format pendidikan bagi masyarakat muslim yang melahirkan output lulusan dan sarjana yang berkontribusi nyata dalam kancah dunia.

\section{DAFTAR PUSTAKA}

Azra, Azyumardi. 2011. ReformsinIslamicEducation: A Global Perspective Seen from the Indonesian Case", dalam Paul Anderson, et.all (ed). Reforms in Islamic Education. University of Cambridge.

Azra, Azyumardi. 2012. Pendidikan Islam; Tradisi dan Modernisasi di tengah Tantangan Milenium III. Jakarta: Kencana.

Daya, Burhanuddin. 1995. Gerakan Pembaharuan Pemikiran Islam; Kasus Sumatera Thawalib. Yogyakarta: Tiara Wacana.

M. Shabir U. 2013. Kebijakan Pemerintah dan PengaruhnyaTerhadap Pendidikan Islam di Indonesia, dalam Jurnal Lentera Pendidikan, Vol. 16 No. 2 Desember 2013

Minhaji, Ach. 2012. Sejarah Sosial dalam Studi Islam. Yogyakarta: Suka Press.

Nata, Abudin. 2012. Sejarah Sosial Intelektual Islam dan Institusi Pendidikannya. Jakarta: Rajawali Pers. 
Steenbrink, Karel A. 1984. Beberapa Aspek Tentang Islam di Indonesia Abad Ke19. Jakarta: Bulan Bintang.

Steenbrink, Karel A. 1974.Pesantren, Madrasah, Sekolah. Jakarta: LP3ES.

Sutrisno. 2011. Pembaharuan dan Pengembangan Pendidikan Islam. Yogyakarta: Fadila Tama.

Sutrisno. 2006. Fazlurrahman; kajian Terhadap Metode, Epistemologi dan Sistem Pendidikan. Jogyakarta: Pustaka Pelajar.

Sirozi, Muhammad. 2004. Agenda Strategis Pendidikan Islam. Yogyakarta: AK Group.

Undang-Undang Sistem Pendidikan Nasional Tahun 2003 